\title{
Selective Breeding, Feeding and Management Practices Followed by Dairy Farmers in Punjab
}

\author{
Anant Simran Singh*, Prabhjot Kaur Sidhu, Aparna and Haneet Kaur
}

Doaba Co-op Milk Producers Union Jalandhar-144008, India

*Corresponding author

\author{
A B S T R A C T
}

\section{Keywords \\ Gross Domestic Product (GDP), FAO}

\section{Article Info}

Accepted:

07 July 2019

Available Online:

10 August 2019
The present study was conducted to know the selective breeding, feeding and management practices followed by dairy farmers in Punjab. A total of 150 farmers were selected randomly and divided into three categories, small $(n=48)$, medium $(n=74)$ and large $(n=28)$. With help of well-structured interview schedule and pretested questionnaire data were collected w.r.t. breeding, feeding and management practices being followed. The data revealed that the farmers offered $20-40 \mathrm{~kg}$ of green fodder and $2-5 \mathrm{~kg}$ of concentrate mixture to dairy animals, but only 23.3 per cent of farmers used mineral mixture regularly. Majority $(86.91 \%)$ of the farmers had adopted artificial insemination for cows but percentage was quite low (21.08\%) in buffaloes. Calf mortality was 22.67 per cent in male calves against 2.67 per cent in female calves. About 49.3 per cent farmers were selling their through middleman as compared to 22.67 per cent and 2 per cent through cooperative societies and self-marketing, respectively. The incidence of reproductive disorders like anoestrus $(13.33 \%)$, repeat breeding $(19.33 \%)$, metritis $(8 \%)$ and retention of placenta $(2 \%)$ were high whereas prevalence of mastitis was observed in 17.33 per cent herds in the area under study. Therefore, study revealed that there is a dire need to educate dairy farmers about feeding, breeding and management practices through better extension contacts, mass campaigns, training as well as mass media in order to sustainable and profitable running of dairy farming in Punjab.

\section{Introduction}

India being an agrarian country, have a large population of livestock which forms an integral part of Indian Gross Domestic Product (GDP) and one of the most important subsidiary occupation for the farmers. Majority of Indian population (72.1\%) is having agriculture as their main occupation (FAO 2001). Forty per cent of people living below poverty line are largely dependent on livestock for their existence (Rao, 1988). With 2 per cent of world's total geographical area,
India has 15 per cent of world's livestock population. Even with such a large livestock population we are lagging behind to suffice daily milk requirements of our country.

Small holder's dairy sector in India is facing several challenges like breeding stock, high cost of feed, non-availability of green fodder round the year, poor management, inadequate health and extension services (Hundal et al., 2010a, b, Wadhwa et al., 2010, Bakshi et al., 2010) which ultimately results in low productivity, poor fertility or infertility in 
dairy cows. Among so many factors affecting dairy farming, feed and fodder scarcity is identified as most limiting constraint accounting for half of total loss followed by problems in reproduction and health (Singh et al., 2015). Many researchers supported nonconventional feedstuffs with higher degradability to feed animals for optimize productive performance (Lamba et al., 2014). The productive and reproductive potential of animals depends upon quality of nutrition, genetic makeup and the animal health system (Ahuja et al., 2003; Udeybir et al., 2012a, b).

The trainings imparted by ICAR, SAUs and KVKs (Hundal et al., 2016a, b, c; Aparna et al., 2016) through trainings further enhanced knowledge level of livestock farmers by manifold also attributed towards improved production potential. With advanced researches being held in the sector of animal nutrition we have achieved increase in milk yield and reduced feed and fodder wastage further leading to better fiber utilization and greater microbial protein synthesis. Economy of dairy farming largely depends upon pregnancy rate after insemination with ultimate aim to receive one calf every year and maximum milk production in case of cows. It is also accepted that bovine genital infections, either specific or non-specific accounts for large number of pregnancy failure among cows (Sirohi et al., 1989).

Planning is required for making livestock much more sustainable which cannot be done without any survey. Studies related to feeding practices and adoption of latest technologies can help to improve our understanding regarding nutritional status of animals and to improve genetic potential of animals (Chatterjee et al., 2007). Keeping the above point in view the present study was undertaken to know the breeding, feeding and management practices followed by dairy farmers in Punjab

\section{Materials and Methods}

The present study was conducted to know the selective breeding, feeding and management practices followed by dairy farmers in Punjab. A total of 150 farmers were selected randomly and divided into three categories, small $(n=48)$ medium $(n=74)$ and large $(n=28)$ dairy farmers. Data was collected by personal interview of respondents with the help of wellstructured and specially designed interview schedule which dealt with the breeding, feeding and management practice in addition to reproductive and productive problems viz. anestrus repeat breeding, retention of placenta, metritis, mastitis and calf mortality, age at first conception and postpartum heat period. The data was analyzed by using software package SPSS version 20.0 (SPSS, 2012) for frequency, percentage etc.

\section{Results and Discussions}

\section{Dairy farming practices adopted by farmers}

\section{Feeding and breeding practices}

All categories of farmers were not allowing their animals to graze. The farmers were offering 20-40 kg of green fodder per animal per day depending upon the season and fodder availability. Only 23.33 per cent farmers were supplementing mineral mixture to their animals (Table 1). The findings are in line with Hundal et al., (2016a) who reported awareness of dairy farmers regarding use of mineral mixture was 22.3 percent. All farmers were offering $2-5 \mathrm{~kg}$ concentrate per day for which animals only. Concentrate feeding was either commercial or homemade (maize, wheat, rice and cotton seed). Dairy farmers were in the habit of feeding 'kahra' to animals immediately after calving. However, concentrate feeding to calves in the herd was practiced by 40 per cent of farmers. Both 
mineral mixture supplementation and concentrate feeding practices were done more in large farms than other categories. Singh et al., (2015) reported that high price of concentrate mixture $(84.4 \%)$ of farmers followed by shortage of feed and fodders (66.6\%), non-availability of input for production and enrichment of green fodder $(40.0 \%)$ and non-availability of concentrates and mineral mixture in villages $(35.5 \%)$ are the major constraints faced by dairy farmers of Punjab.

The farmers preferred to rear buffaloes than cows due to their more resistance against parasitic and other infection, ability to survive under adverse feeding by environmental conditions etc. Overall majority (86.91\%) farmers had adopted artificial insemination for cows in their herd (Table 1). However only 21.08 per cent farmers were using artificial insemination in buffaloes, but majority (78.91) farmers adopted natural service. Similarly, Panwar et al., (1994) reported that artificial insemination was adopted by lower number of farmers $(7.73 \%)$ in buffaloes as compared to 46.85 per cent farmers in cows. This may be due to the lower conception rate in buffaloes than cows by artificial insemination.

\section{Selective management practices}

Overall majority $(88.00 \%)$ farmers under study were using full palm method of milking that decreases the chances of mastitis (Table 1). This indicates that majority of the farmers were aware of correct method of milking. Contrary to the finding Hundal et al., (2013) reported that only 4.7 percent of dairy women had belonged to high knowledge level w.r.t. clean milk production practices and about 38 percent were aware about full palm method of milking as accurate method of milking. In present study, mastitis was reported in 17.33 per cent herds. Calf mortality was in 22.67 per cent farms in male calves and mortality was only at 2.67 per cent in female calves. This indicates ignorance of dairy farmers towards male calve rearing. Common management practices like proper feeding, vaccination and deworming practices are done mostly in female calves only as they consider them future dairy animals.

As for as the marketing is concerned, 49.3 percent farmers were selling their milk to milkmen. The self-marketing was adopted by only 2 per cent dairy farmers. Milk sold to the co-operative society was by 22.7 per cent farmers (Table 1).

Overall 48.67 per cent farmers deworm their animals. Adoption of deworming was more by large farmers $(85.71 \%)$ as compared a small $(31.25 \%)$ and medium (45.94\%) farmers. This may be due to production level, economic status, extension contacts and awareness of farmers. Similarly Hundal et al., (2016d) reported that without undergoing exposure of training only 37 percent farmers had familiar with deworming. Overall 90.97 per cent of dairy herds were vaccinated in the area under study. Singh et al., (1998) observed that 82.50 per cent farmers under their study had adopted vaccination in their herd. Vaccination against FMD and HS disease was adopted by more number of farmers than deworming because vaccination facility was provided by the Government Department at subsidized rate and Government department is bringing a lot of awareness among farmers.

According to majority (54.76\%) farmers having cows, the age at first calving was 2-3 years in cows. However, it was $>3$ years in buffaloes as reported by majority of (59.89) farmers rearing buffaloes. This is due to the fact that maturity period is less in cows as compared to buffaloes. Usual postpartum time period in both cows and buffaloes was 2-3 months as perceived by majority of famers under study. 
Table.1 Common dairy farming management practices followed by farmers

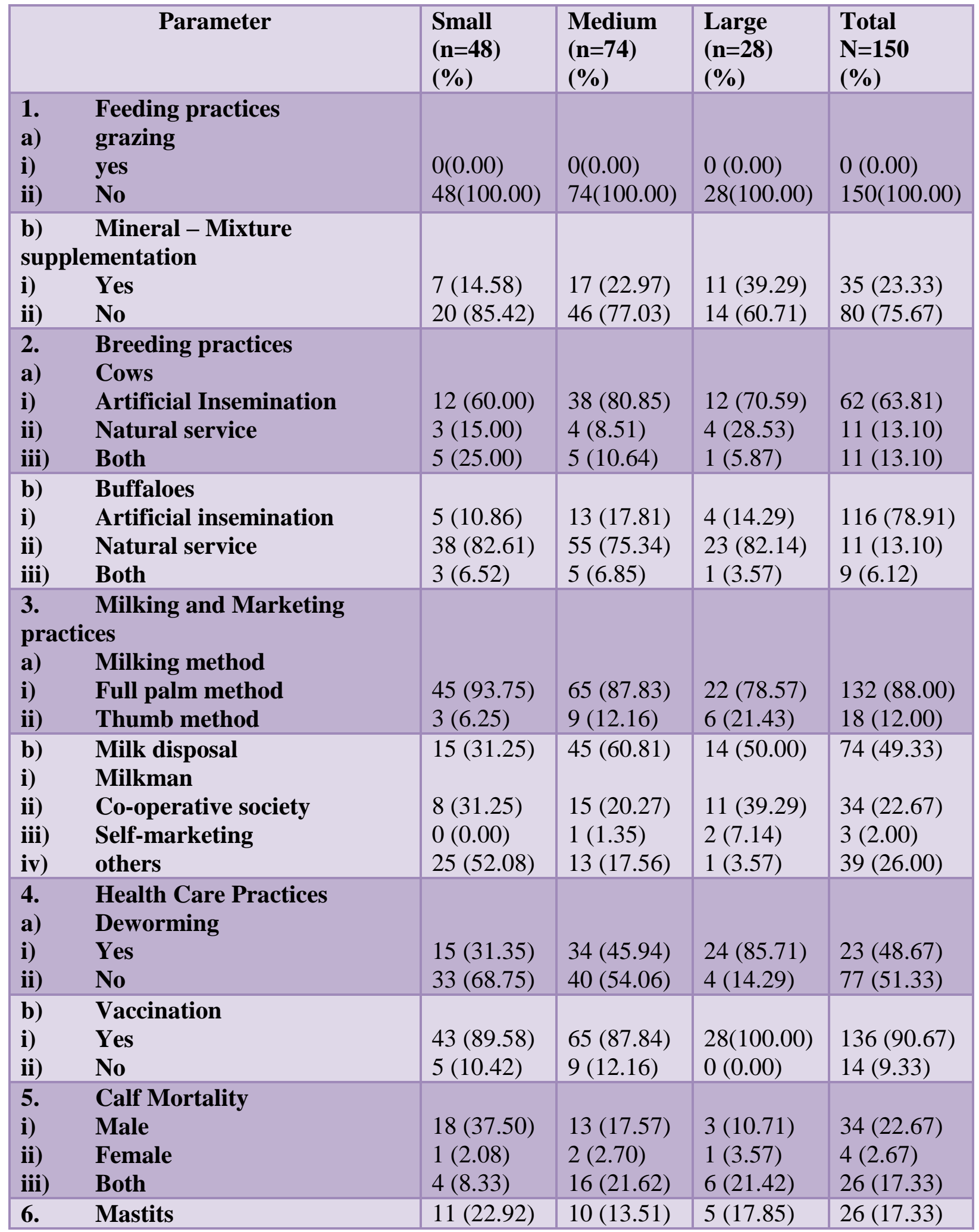


Table.2 Incidence of reproductive disorders of selected dairy farms

\begin{tabular}{|ll|l|l|l|l|}
\hline Reproductive disorder incidences & $\begin{array}{l}\text { Small } \\
(\mathbf{n = 4 8}) \\
(\mathbf{\%})\end{array}$ & $\begin{array}{l}\text { Medium } \\
(\mathbf{n = 7 4 )} \\
(\mathbf{\%})\end{array}$ & $\begin{array}{l}\text { Large } \\
(\mathbf{n = 2 8}) \\
(\mathbf{\%})\end{array}$ & $\begin{array}{l}\text { Total } \\
\text { respondents } \\
\mathbf{N = 1 5 0}(\mathbf{\%})\end{array}$ \\
\hline i) & Anoestrus & $3(6.25)$ & $13(17.57)$ & $4(14.29)$ & $20(13.33)$ \\
\hline ii) & Repeat breeding & $8(16.67)$ & $14(18.92)$ & $7(25.00)$ & $29(19.33)$ \\
\hline iii) & Retention of Placenta & $5(10.42)$ & $4(5.41)$ & $3(10.71)$ & $12(8.00)$ \\
\hline iv) & Metritis & $1(2.00)$ & $1(1.35)$ & $1(3.57)$ & $3(2.00)$ \\
\hline
\end{tabular}

\section{Reproductive disorder incidences}

Incidence of anoestrus, repeat breeding, metritis and retention of placenta was reported at 13.3, 19.3, 8 and 2 per cent dairy farms respectively (Table 2). According to Singh (2004) anestrus $(31.98 \%)$ was the major among other reproductive disorders. However, Atwal et al., (2002) and Tomer et al., (2002) reported 30.10 and 55.99 to 66.73 per cent incidence of anestrus, respectively in dairy animals. Incidence of repeat breeding was 14.67 and 32.2928 .84 per cent as reported by Singh et al., (1998) and Singh (1979), respectively. This variation may be due to difference in adoption of management practices. Incidence of retention of placenta was 14.64 per cent in study conducted by Singh (2004) and the difference in results may be due to variation in general health and level of nutrition.

The study revealed that the improved dairy farming practices especially feeding are still not up to the mark in the field. Therefore, there is a dire need to educate dairy farmers about feeding, breeding and management practices through better extension contacts, mass campaigns, training as well as mass media in order to sustainable and profitable running of dairy farming in Punjab.

\section{References}

Ahuja, V., Kenneth, E., McConne, Dina-Umali, D. and Hann, C. (2003). "Are the poor willing to pay for livestock services? Evidence from rural India”. Indian Journal of Agriculture Economics, 58(1):
84-99.

Aparna, Hundal, J.S. and Chahal, U.S. 2016. Impact of specialized trainings of dairy farming on the knowledge level of farmers in Punjab. Vet Sci Res J 7 (2): 7982.

Atwal, K.S., Prabhaker, S. and Ghuman, S.P.S. 2002. Prevalence of various reproductive disorders in buffaloes in seliniferous areas of Punjab. Indian J. Anim. Reprod. 23: 187-188.

Bakshi, M.P.S, Wadhwa, M and Hundal, J.S. (2010) Nutritional status of animals in peri urban dairy complexes in Punjab Ind. J Ani Sci. 80: 745-749

Chatterjee, A. Singh, R.B., Saha, R.C. and Roy, P.K. (2007). Feeding practice and nutritional status in dairy cattle in rural households of old Alluvial zone in West Bengal. Indian J. Dairy Sci. 60(6): 408412.

FAO 2001. Total population, agriculture population and economically active population. In: Production year book 201. Vol. 55 pp 19-26. FAO Statistical series no. 170. Chief, Publishing Management Service, Information Division, FAO, Viale delle Terme de Caracalla, 00100 Rome, Italy.

Hundal, J. S., Chandrahas, Kaur, K., Singh, J. and Verma, H.K. 2013. Clean milk production awareness among women dairy farmers of Punjab. Vet. Practitioner 14(2): 394-97.

Hundal, J.S., Aparna, Chahal, U.S. and Bhatti, J.S. 2016a. Methodological investigation of cognitive domain of dairy farmers on the practice of mineral mixture 
supplementation and its interaction with socio personal characters, Indian $J$ of Animal Nutr. 33 (2): 164-168.

Hundal, J.S., Chahal, U.S., Bhatti, J.S. and Kansal, S.K. 2016b. Evaluating perceived effectiveness of specialized training on pig farming. Economic Affairs 61 (1): 1721.

Hundal, J.S., Chahal, U.S., Kansal, S.K. and Bhatti, J.S. 2016d. Role of training in changing knowledge level among dairy farmers of Punjab the Haryana Veterinarian 55: 220-223.

Hundal, J.S., Chahal, U.S., Singh, N., Kansal, S.K. and Bhatti, J.S. 2016c. Impact of training on knowledge level of goat farmers in Punjab. The Haryana Veterinarians 55: 47-49.

Hundal, J.S., Kaur, J, Wadhwa, M and Bakshi, M.P.S (2010a) Nutritional status of animals in sub mountainous undulating zone of Punjab. Ind. J. Dairy Sci. 62: 280285.

Hundal, J.S., Sharma, R, Gupta, J and Gupta, A (2010b) Mastitis awareness and factors influencing the knowledge among dairy farmers of Punjab. Ind J Dairy Sci. 63: 128-131.

Lamba, J.S., Hundal, J.S., Wadhwa, $M$ and Bakshi, M.P.S. (2014). In-vitro methane production potential and in-sacco degradability of conventional and nonconventional protein supplements. Indian J Anim Sci 84: 539-42.

Panwer, P.S., Malik, P.S. and Tomer, O.S. 1994. Studies on managemental practices of

Rao, M.V. 1988. Scope of Institutional

Singh, J. 2004. Study on incidence of reproductive disorders in dairy animals vis-à-vis various management practices.
M.V.Sc. Thesis, Punjab Agricultural University, Ludhiana, Punjab, India.

Singh, P., Hundal, J.S., Bhatti, J.S., Singh, U. and Kansal, S.K. 2015. Constraints faced by farmers in adoption of dairy as entrepreneurship. The Haryana Veterinarian 54 (1): 67-69.

Singh, R.B., 1979, Studies on infectious causes of repeat breeding and their responses to treatment in bovines. M.V.Sc. Thesis, Punjab Agricultural University, Ludhian, Punjab, India.

Singh, T.P., Fulzele, R.M. and Nath, A. 1998. Study on adoption of improved dairy husbandry practices among tribals and chhota Nagpur region. Dairy Guide19: 53-58.

Sirohi, N.S., Monga, D.P. and Knar, S.K. Microbiological studies on some reproductive disorders of cattle. Indian J. Anim. Sci. 1989; 59(5): 537-541.

Tomar, K.P.S., Singh, P., Singh, R. and Singh S. 2002. Seasonal variation in reproductive problems of buffaloes under field conditions. Indian J. Anim. Reprod. 23: $18-20$.

Udeybir, S., Hundal, J.S., Singh, J., Verma, H.K. and Sahota, R.S. 2012a. Bovine herd management practices adopted in PeriUrban Dairies of Ludhiana District in Punjab. Ind. J Ani. Prod. Mgt. 28: 47-50

Udeybir, S., Hundal, J.S., Singh, J., Verma, H.K. and Sahota, R.S. 2012b. Breeding and health management practices adopted in Peri-Urban Dairies of Ludhiana Wradidh.,JHennedalMggsit.amid1Bakksh3, M.P.S. (2010). Nutritional status of animals of flood prone zone of Punjab Ind. J Ani Sci. 80: $547-550$.

\section{How to cite this article:}

Anant Simran Singh, Prabhjot Kaur Sidhu, Aparna and Haneet Kaur. 2019. Selective Breeding, Feeding and Management Practices Followed By Dairy Farmers in Punjab. Int.J.Curr.Microbiol.App.Sci. 8(08): 754-759. doi: https://doi.org/10.20546/ijcmas.2019.808.085 